Revista de Economia Política, vol. 32, no 1 (126), pp. 55-71, janeiro-março/2012

\title{
Desigualdade, mas de qual falamos?
}

\section{CLAUDIO SALVADORI DEDECCA*}

What inequality are we talking about? The essay was motivated by the recent disclosure of documents by multilateral development institutions demonstrating that the last phase of economic growth has tended to aggravate socioeconomic inequality. The purpose of the current analyze is to debate the advances that have been made and the persisting methodological and analytical difficulties in the debate on inequality as well as to contribute with a few insights towards the construction of a multidimensional view of a recurring and inherent aspect of capitalist development.

Keywords: inequality; income distribution; welfare; development; social policy.

JEL Classification: I30; O15.

Este ensaio foi motivado pela divulgação recente de alguns documentos das instituições multilaterais de desenvolvimento, que identificaram que o crescimento deste início de século vinha carregando consigo uma tendência de aumento da desigualdade socioeconômica. Merecem destaque três desses documentos:

- The Inequality Predicament, relatório sobre a situação social no mundo realizado pelas Nações Unidas (UN, 2005);

- Equality at work: Tackling the challenges, relatório encaminhado pelo Diretor da OIT à $96^{\text {a }}$ Conferência Internacional do Trabalho (ILO, 2007);

\footnotetext{
* Professor titular do Instituto de Economia da Universidade Estadual de Campinas, Unicamp. E-mail: claudio.dedecca@gmail.com. Este ensaio é parte de um estudo mais amplo sobre desigualdade no Brasil, estruturado em cinco documentos com os enfoques seguintes: (1) desenvolvimento capitalista e a inevitável recorrência da desigualdade; (2) desigualdade, mas de qual falamos?; (3) desenvolvimento, instituições e desigualdade, possibilidades metodológicas de mensuração; (4) a desigualdade nos países da OECD em uma perspectiva multimensional; e (5) a desigualdade na sociedade brasileira, um enfoque multidimesional. O projeto teve o financiamento da Coordenação de Aperfeiçoamento de Pessoal de Nível Superior, Capes, Brasil. O autor agradece o apoio e a amizade dos Professores Pierre Salama (Centre d'Économie da Université Paris Nord) e Jacques Freyssinet (Centre d'Études d'Emploi), que viabilizaram as melhores condições para o desenvolvimento do estudo na França em 2009-2010. Submetido: 7/agosto/2009; Aprovado: 18/junho/2010.
} 
- Growing Unequal? - Income distribution and poverty in OECD countries, documento produzido pela OCDE (OECD, 2008).

Como afirma o documento das Nações Unidas logo em sua apresentação, ignoring inequality in the pursuit of development is perilous. Focusing exclusively on economic growth and income generation as a development strategy is ineffective, as it leads to the accumulation of wealth by a few and deepens the poverty of many; such an approach does not acknowledge the intergenerational transmission of poverty. A broader approach to poverty reduction includes social, economic and political dimensions, integrating improvements in health, education, economic development, and representation in legislative and judicial processes. It is the implementation of policies in these areas that contributes to the development of human capital, enabling the poor to realize their full productive potential. Addressing all aspects of poverty increases the odds that future generations will reap the benefits of today's policies rather than remaining trapped in a cycle of poverty.

Inequalities in income distribution and in access to productive resources, basic social services, opportunities, markets, and information can cause and exacerbate poverty. As emphasized in the recommendations of the World Summit for Social Development, it is crucial that policies and programmes for poverty reduction include socio-economic strategies to reduce inequality (UN, 2005, p. 1).

É inegável que a eclosão da crise internacional no segundo semestre de 2008 exige que sejam reavaliados, ao menos, parte dos argumentos encontrados nestes documentos. É amplamente reconhecida a larga amplitude da crise atual, que exige das políticas públicas um esforço para além de uma correção de rota da trajetória de crescimento. Apesar do expressivo esforço político que tal tarefa demandará para o restabelecimento do crescimento em uma perspectiva de desenvolvimento associado à redução da desigualdade socioeconômica, é inegável que os desafios propostos pelos documentos continuam tendo ampla pertinência para a política pública. Ganha centralidade e abrangência o debate sobre as políticas e ações orientadas para a redução da desigualdade. Todos os documentos reconhecem a necessidade de adoção de políticas e ações que contribuam para uma distribuição do excedente menos desigual.

Este eixo comum aos documentos, valorizado pela crise atual, permite explicitar uma pergunta-chave encontrada ao menos em dois deles e que conduzirá o desenvolvimento deste ensaio. É possível construir políticas e ações orientadas para a redução da desigualdade centradas na distribuição de renda monetária e, mais especificamente, daquela auferida no mercado?

Como coloca o documento da OCDE em sua conclusão: Can we assess economic inequalities just by looking at cash income? The short answer to this question is "no". There are three reasons why cash income is a limited measure of the economic resources of households. First, people can have quite high living standar$d s$ even if they have low incomes - because they have built up their savings, because government services such as health and education may be provided free of charge, or because they can produce much of what they need through home production. Second, income is only an indirect measure of people's consumption op- 
portunities, and better proxies - such as household wealth and actual consumption - are sometimes available. Third, the calendar year underlying the concept of annual income is an accounting concept with no intrinsic economic significance, and the situation that prevails at a point in time may be a poor guide to people's conditions over their life-course. Cash income is easily measured, and this helps cross-country comparisons, but any serious attempt to assess developments in economic inequality has to consider whether these other factors validate or invalidate conclusions based on static income measures alone (OECD, 2008, p. 294).

$\mathrm{O}$ ensaio tem o objetivo de organizar os avanços e as dificuldades de natureza metodológica e analítica presentes no debate sobre desigualdade e apontar algumas pistas para a construção de uma visão multidimensional de um aspecto recorrente e inerente ao desenvolvimento capitalista. As razões desta preocupação se voltam para a discussão sobre a distribuição de renda no Brasil. Nos últimos anos, a Pesquisa Nacional por Amostra de Domicílios tem mostrado uma queda da desigualdade. É preciso reconhecer a importância deste processo em um país marcado por fases recorrentes de crescimento com aumento da desigualdade. Pela primeira vez tal movimento não ocorreu. É fundamental apontar este fato, bem como é decisivo que se reconheçam os limites que ele per se apresenta.

$\mathrm{O}$ ensaio procura contribuir para o debate em uma perspectiva que amplie o enfoque da análise sobre a desigualdade para além da distribuição de renda oriunda do mercado, isto é, do trabalho, da previdência social e da transferência pública de renda. Ele fará um recorrido da literatura internacional de modo a indicar os limites do enfoque prevalecente na análise da situação brasileira, bem como ele procurará ordenar algumas sugestões metodológicas a serem exploradas com o objetivo de estruturar uma visão mais ampla da desigualdade, como aparece nos documentos internacionais mencionados e que, certamente, trará uma contribuição mais substantiva para a construção da política pública. ${ }^{1}$

\section{A NECESSIDADE DE SUPERAÇÃO DO CONCEITO DE RENDA BASEADO NA VISÃO DE HICKS}

Em ensaios produzidos nas décadas de 1930 e 1940, John Hicks (1939, 1940 e 1948) procurou sistematizar uma determinada visão de renda que teve ampla aceitação pelos economistas, com forte influência na definição metodológica para

\footnotetext{
${ }^{1} \mathrm{O}$ ensaio tem natureza teórica-metodológica, focando seus argumentos na necessidade de se ampliar o enfoque sobre a desigualdade para além dos indicadores de concentração calculados a partir da renda corrente. Apesar da inegável importância do tema, ele não tratará da relação entre crescimento e pobreza, tarefa que exigiria um esforço específico. Dados das instituições internacionais apontam que avanços importantes têm sido observados em termos de redução da pobreza, mesmo em situação de incremento da desigualdade de renda (Sachs, 2005). Pelo mesmos motivos, ele não abordará possíveis impactos de regimes econômicos baseados em economias abertas e seus impactos sobre a desigualdade entre e intrapaíses (Galbraith, 2005).
} 
a consolidação dos Sistemas de Contas Nacionais. ${ }^{2}$ Focada na sua dimensão monetária (money income), o autor considerava importante incorporar ao conceito de renda individual as transferências monetárias feitas pelo governo, exclusive impostos, e a renda monetária excedente à manutenção do valor real do patrimônio individual. Estabelecia-se o conceito de renda disponível.

Do ponto de vista conceitual, o autor ampliava a noção de renda monetária para além daquela oriunda da atividade produtiva ou do trabalho (market income). Em um ensaio crítico, Roberto Eisner (1989) sintetiza que o concept of income [de Hicks] is that wich we can consume while keeping our real wealth intact. Em seguida o autor apresenta afirma: but this is a far cry from the usual measures of individual incomes, corporates profits or the aggregates of personal and national income (Eisner, 1989, p. 2). Esta afirmação é respondida pelo próprio autor com alguns exemplos da impossibilidade de se chegar ao resultado proposto por Hicks. Os principais por ele apontados são: a mudança no custo da depreciação pelo motivo do capital se tornar mais intensivo; dificuldade de se estimar o ganho real de renda pela dificuldade de conhecer com precisão mudanças na taxa de inflação; a complexidade do impacto do aumento da produtividade sobre a renda; e a entrada da mulher no mercado de trabalho, cuja ocupação tem rendimento superior ao observado nas atividades domésticas, dentre outras situações que impedem de se calcular a renda esperada. Eisner explicita deste modo a impossibilidade de se saber a priori a variação futura da renda real com o objetivo de decidir a função de gasto, de tal modo que, ao final do período, o valor real do patrimônio venha a estar imutável.

Os questionamentos feitos por Eisner revelam uma fragilidade teórica da construção de Hicks, decorrente do fato do autor ter sido obrigado a adotar a hipótese de determinação instantânea da renda esperada e da renda auferida. Isto é, Hicks supôs que todos os indivíduos estimam sua renda futura e acertam no gasto, de tal modo que ao final do período a despesa corresponda à renda corrente monetária mais o ganho excedente da variação real do patrimônio. Isto é, os indivíduos seriam suficientemente racionais e detentores de informação para estimarem e acertarem exatamente sua renda de mercado, a taxa de inflação, a depreciação, dentre outros fatores, para determinarem seu gasto sem que o valor da riqueza real seja alterado.

Zacharias (2002, p. 2) explora mais detalhadamente esta dificuldade, afirmando que para Hicks, the motivation for the definition of income is purely subjective, in the sense that such a definition must facilitate "prudent conduct" for the individual. The central meaning of income is also subjective for him in the sense that it is formulated in terms of the individual's expectations. In fact, Hicks considered

\footnotetext{
${ }^{2}$ Os trabalhos de Hicks desdobram as contribuições anteriormente realizadas por Haig (1921) e Simons (1938), razão que tanto a literatura econômica como as agências governamentais denominam o conceito de renda formulado pelos autores como Haig-Simons-Hicks (HSH). Apesar da origem da contribuição estar nos esforços dos três autores, foram os ensaios de Hicks que acabaram se tornando a referência para todo o debate posterior sobre renda (Hicks, 1939, cap. 14, 1948).
} 
only subjective definitions of income as theoretically meaningful because only they are relevant for individual decisions.

A visão de Hicks sobre a renda é despossuída de qualquer noção de incerteza. As dificuldades encontradas na visão do autor são ainda maiores, como mostra Kuznets ao discutir a medição da renda social. Dentre as diversas questões levantadas por Kuznets (1948a e 1948b), merece destaque aquela que discute a dificuldade em conhecer a priori o resultado da receita pública em razão de possíveis mudanças na composição dos impostos em decorrência da possibilidade de substituição de produtos por parte dos indivíduos, bem como a sua devida identidade (equilíbrio) com o resultado das diversas categorias de gasto público e seu impacto sobre a renda disponível dos indivíduos e famílias (Musgrave, 1985).

Ademais, como escreveu o autor, Professor Hicks does not discuss the welfare implications of social income beyond formulating the criteria by with increase or decline in welfare can be established (Kuznets, 1948, p. 5).

É inegável a simplificação do conceito de renda, que, em grande medida, encontrou no período de crescimento do após-guerra nos países centrais alguns elementos que minimizaram as limitações que ele apresentava. O contexto de pleno emprego, assentado na preponderância do assalariamento e de uma regulação pública social e econômica extensa nos países avançados, deu razoável representatividade ao conceito de renda derivada do trabalho e das transferências públicas monetárias, quando os lucros eram distribuídos uma ou duas vezes por ano e eles não se confundiam com a remuneração do trabalho ou de gestão cotidiana do capital.

O crescimento do após-guerra plasmou um período particular de redução da desigualdade nas economias capitalistas desenvolvidas, fundada em uma sociedade salarial expressa na dominância das rendas do trabalho acrescida da transferência pública de renda monetária. Alterando o argumento de Weber (1992), pode-se dizer que o trabalho e o reconhecimento de seus frutos forjaram uma versão moderna e menos desigual do capitalismo e de seu espírito.

Como argumentou Polanyi, the protection of man, nature, and productive organization amounted to an interference with markets for labour and land as well as fort the medium of exchange, money, and thereby, ipso facto, impaired the self regulation of the system. Since the purpose of the intervention was to rehabilitate the lives of men and their environment, to give them some security of status, intervention necessarily aimed at reducing the flexibility of the wages and the mobility of labour, giving stability to incomes, continuity to production, introducing public control of national resources, and the management of currencies in the order to avoid unsettling changes in the price level (Polanyi, 2001, p. 225).

O estudo de Polanyi antecipou ademais que a regulação pública do após-guerra, restrita aos países desenvolvidos e com particularidades nacionais relevantes, foi produto de mudanças recorrentes das economias capitalistas, devido à instabilidade dos mercados exigir maior presença do ente público em várias esferas da economia. A complexidade da produção e da organização capitalistas passou a 
exigir, mesmo contra a vontade de certos segmentos da sociedade, a presença da esfera pública tanto reguladora como empreendedora (Shonfield, 1965).

Neste processo emergiram setores de atividade econômica, cujo processo teve a ação do Estado como determinante para sua constituição e funcionamento. Bens e serviços não mercantilizados ou parcialmente mercantilizados, como a educação básica e a saúde. $\mathrm{O}$ acesso a estes bens e serviços plasmou a separação do nível de bem-estar dos indivíduos e das famílias do poder de compra associado à renda corrente auferida via mercados. Esta separação se estabeleceu de forma extremamente relevante na política social, que foi decisiva para a elevação do bem-estar no capitalismo contemporâneo (Marshall, 1967).

O progressivo distanciamento do nível de bem-estar dos indivíduos e das famílias em relação à renda corrente foi tema explorado por Kuznets (1948b) na crítica à formulação de Hicks.

Novos elementos foram apresentados por Kuznets no ensaio clássico de 1955, quando o autor introduziu explicitamente o argumento do papel das instituições públicas (government) para o estado de desigualdade (Kuznets, 1955). O autor explicitou a noção de renda disponível, correspondente à renda monetária acrescida do resultado líquido das taxas e impostos. Ademais, ele apontou a necessidade de incorporar a discussão sobre desigualdade as transferências públicas ou o consumo não monetários (income in kind) e a renda propiciada pela posse de ativos monetários (assets), bem como a transferência de ativos não monetários entre gerações.

Infelizmente, a ampla difusão do ensaio de 1955 ficou restrita ao debate sobre trajetória da desigualdade em formato de uma curva U invertida. Entretanto, como explicitamente reconheceu o autor, for the study of economic growth of nations, it is imperative that we become more familiar with findings in those related social disciplines that can help us understand population growth patterns, the nature and forces in the technological change, the factor that determine the characteristics and trends political institutions, and patterns of behaviour of human beings. Effective work in this field necessarily calls for a shift from market economics to political and social economy (Kuznets, 1955, p. 28).

\section{RENDAS DE MERCADO E DISPONÍVEL E A DESIGUALDADE, UM ENFOQUE LIMITADO JÁ EM SUA ORIGEM}

O percurso analítico realizado evidencia que a análise da desigualdade construída com enfoque na renda de mercado ou corrente foi objeto de discussão minuciosa entre os economistas ao menos desde o final dos anos 1930. Do ponto de vista deste ensaio, merecem destaque os trabalhos da conferência de 1971 organizados e publicados por Moss (1973).

$\mathrm{Na}$ introdução, Moss explicitava os termos do debate que se processava em torno do tema à época: Gross national product, the principal output of the accounts, was under attack both as a goal national effort ands as a measuring Rod of economic performance. Some have deplored the pursuit of high in the GNP as a goal, 
asserting that it distorts national priorities, does not improve or may even worse the distribution of income, and irreparably damages the environment. Critics have asserted that countries whit the highest level of GNP are not necessarily the ones with the highest expectancy, lowest crime rate, or cleanest air. Critics have charged that as a measuring rod GNP gives incorrect indications of changes in the welfare mainly because it fails to allow for the disamenities associated with industrial growth, particularly pollutions of air and water. Some have also argued that even apart from not serving as an adequate index of welfare, which it was not designed to do, GNP fails to serve as an accurate index of economic growth, in large part because it does not include appropriate measures of economic performance of households and governments (Moss, 1973, p. 1).

Os ensaios desse livro tiveram importante repercussão, sendo que aquele escrito por Nordhaus e Tobin (1973) continua sendo uma referência importante para o debate atual sobre renda, bem-estar e desigualdade, bem como a reflexão de Kuznets (1973) ao final do livro.

A relevância do ensaio de Nordhaus e Tobin se deveu à proposta dos autores de contestar de um lado a tese que minimizava a importância do crescimento para a condição de bem-estar da população e por outro de explorar a necessidade de analisar esta relação de forma mais complexa para além das relações e resultados estabelecidos no âmbito dos mercados fundados na troca monetária.

A preocupação do ensaio era explicitamente apresentada pelos autores: We have chosen to direct our attention to three important problems raised by those who question the desirability and possibility future growth: (a) how good are measures of output currently used for evaluating the growth of economic welfare? (b) does the growth process inevitability waste our natural resources? (c) how does the rate of population growth affect economic welfare? In particular, what would be the effect of zero population growth? (Nordhaus e Tobin, 1973, p. 512). Das quatro indicadas, é a primeira que encontra referência com a preocupação deste ensaio.

O foco na primeira se deve ao fato dos autores explicitarem as dimensões da situação de bem-estar que lhes interessava, tornando evidente a limitação do enfoque construído a partir das rendas de mercado ou disponível. O esforço dos autores se consolidou na construção de um indicador de bem-estar (measure economic welfare - MEW) que, como eles próprios afirmaram, ... attempt to allow for the more obvious discrepances between GNP and economic welfare ...Our MEW is largely a rearranjement of items of national accounts ... Our adjustments to GNP fall into three general categories: reclassification of GNP expenditures as consumption. Investment, and intermediate; imputation for the services of consumer capital, for leisure, and for the product of household work; correction for some of disamenities of urbanization (Nordhaus e Tobin, 1973, pp. 512-513). O resultado obtido para a MEW foi próximo de duas vezes o PIB per capita.

Foram duas as principais inovações encaminhadas pelos autores.

A primeira apontou a necessidade de se incorporar o valor de alguns produtos que, como eles próprios dizem, são consumidos em natura. Os exemplos dados foram os produzidos pelo Estado, como segurança pública, manutenção de estradas 
ou defesa nacional. A sociedade consome estes serviços, mas eles não são computados pelas contas nacionais, por não ser objeto de transação monetária.

A segunda inovação apontou a necessidade de imputar valores para serviços de capital, lazer e trabalho não realizado para o mercado: The omission of leisure and of nonmarket productive activity from measures of production conveys the impression that the economists are blindly materialists (Nordhaus e Tobin, 1973).

As preocupações dos autores foram reiteradas em outros ensaios presentes no livro e reconhecidas por Kuznets (1973) em um conjunto de observações elaboradas à guisa de uma conclusão da obra: It is with reference and constraint that the problems in the measurement of net product arrive, reflecting the limitations of current measure. These limitations should not be viewed as matter of intellectual wilfulness, but as results of deeply rooted measurement problem, and of the difficulty of agreement on underlying concepts and on assumed analytical relations (Kuznets, 1973, p. 580). O ponto de vista do autor era mais amplo, indicando a necessidade de considerar a contribuição do estoque de bens duráveis nos domicílios, bem como os estoques de capital intangível como educação e outros bens que afetam positivamente o bem-estar, o de conhecimento e de capacidade tecnológica, ou o conhecimento social e das instituições a ele associadas.

Kuznets reconhecia a dificuldade de identificar uma lista de problemas sobre a forma de mensuração do produto e da renda que não incorresse em algum tipo de omissão. Contudo, argumentou: the list suggest two reflections. The first is that the problems are numerous, and recalcitrant; and would require a variety of sustained experimental and imaginative research before answers and measured are established. Second, in their character and recalcitrance, there are all questions of long standing in the national literature, belonging to the problems of inclusion or drawing the diving line between economic and noneconomic, on the one hand, and productive and unproductive, on the other; of netness and grossness - of distinguishing between cost and returns, between intermediate and final products, and of valuation, i.e., of meaningful weighting system by with to combine the diverse costs and net economics products into acceptable and articulated totals. These are of groups of questions ... in somewhat different form and language, these questions were foci of repeated discussions in the economic literature going back now some two centuries, or longer (Kuznets, 1973, pp. 583-584).

O autor reconhecia não somente a recorrência que o debate sobre a mensuração do produto, e por consequência da renda, na literatura econômica, como a inegável importância de se ampliar o escopo teórico-metodológico prevalecente.

Ademais, segundo Kuznets, ... the increasing complexity of economic structure resulting from economic growth, the large monopolistic scale of the productive units, and the necessity of controlling the continuous, incipient conflicts generated bys structural shifts in the course of modern economic growth called for a greatly augmented governmental apparatus - for economic regulation, for responding to pressures for greater equality of economic opportunity, and later for greater economic society, and finally for assuring the international position of an economic society organized under a sovereign state in the age of intensified nationalism. The 
relevance of the resulting government output to the final goal of economic activity was brought sharply into question by the great rise not merely in the absolute, but in the proportional, magnitudes of resources devoted to government consumption in the rapidly growing developed countries (Kuznets, 1973, p. 585).

De outra forma, o autor retoma os argumentos de Polanyi e Marshall, anteriormente mencionados, ao apontar a necessidade de compreender o crescimento como um processo que amplifica progressivamente a complexidade institucional do capitalismo, expressa tanto nas formas de produção de bens e serviços como naquelas referentes ao seu consumo.

O fato relevante a ser analisado do ponto de vista teórico e metodológico é a crescente complexidade institucional que o desenvolvimento capitalista carregou e carrega. Ela reduziu o papel do mercado de trabalho para a constituição da situação de bem-estar e de desigualdade socioeconômica.

Faz-se necessário que toda avaliação da situação de desigualdade em qualquer sociedade rompa o enfoque centrado na renda. Esta superação é necessária mesmo que esteja se discutindo a desigualdade de natureza econômica, pois esta tem raiz relevante mas não exclusiva na renda monetária auferida pelos indivíduos e famílias. No campo da produção e da renda, os últimos 30 anos foram marcados por uma diversificação das formas de apropriação e gestão de patrimônio com fortes implicações sobre a renda disponível. Em outra dimensão, a difusão ampla das tecnologias da informação se traduziu objetivamente no estabelecimento de novas formas de linguagem e conhecimento com um amplo potencial presente e futuro de influenciar sobre o bem-estar e a desigualdade socioeconômica.

A principal razão para buscar uma perspectiva mais ampla, que supere os marcos tradicionais adotados em economia para analisar a desigualdade socioeconômica, foi muito bem explicitada por Juster (1973): To identify and establish the quantitative significance of social and economic problems and priorities, policy makers need, among others types of information, a set or sets of accounts which describe the significant dimensions of the system for which they are responsible. Also, a system if comprehensive performance measures is clearly indispensable both for any evaluation of changes in policy and for analysis of policies alternatives (Juster, 1973, p. 27).

\section{A AMPLIAÇÃO DO ENFOQUE SOBRE DESIGUALDADE PARA ALÉM DA RENDA}

Graças aos esforços de instituições multilaterais e nacionais e de pesquisadores acadêmicos, uma diversidade ampla de proposições tem emergido nestes últimos anos. Alguns destes esforços se defrontaram com o enfoque multidimensional da desigualdade socioeconômica. Esta perspectiva não implica o abandono da dimensão da desigualdade tradicionalmente considerada em economia centrada na renda monetária. Na perspectiva de abordagem multidimensional, a renda monetária é tomada como uma das dimensões. 
O ponto de partida funda-se em dois documentos de instituições multilaterais de desenvolvimento, com amplo potencial de influência sobre instituições públicas e o debate acadêmico:

- Expert group on household income statistics, report and recommendations, documento elaborado por diversas instituições multilaterais (Canberra Group, 2001);

- Household income and expenditure statistics, relatório elaborado pela Conferência dos Estatísticos do Trabalho da Organização Internacional do Trabalho (ILO, 2003).

Ambos os documentos se centram na mensuração da renda dos domicílios, bem como aceitam o enfoque tradicional contruído a partir da formulação de Hicks, já comentada neste ensaio.

O documento elaborado pelo Canberra Group contou com a participação de instituições internacionais como a OECD, Banco Mundial e a OIT, bem como de diversas instituições nacionais de estatísticas de países desenvolvidos e em desenvolvimento. A própria elaboração do documento revela a insatisfação atual das instituições internacionais e nacionais com as metodologias que orientam a produção das bases de dados sobre renda dos domicílios.

A contribuição deste documento volta-se principalmente para a necessidade de se contabilizar três formas de renda ainda pouco conhecidas no momento histórico presente. São elas: as transferências públicas em espécie, isto é, em serviços diretos (social transfer in-kind, STIK); a renda implícita oriunda da propriedade do domicílio; e a renda de capital/patrimônio (net worth) e da produção de bens e serviços para próprio consumo. Ele propõe uma construção em dois estágios. A primeira se incorpora à definição de renda disponível (disposable income), entendida como o somatório da renda de mercado, a resultante das transferências monetárias (contribuição para a previdência social, plano de saúde pago pelo empregador e taxas e impostos pagos) e as transferências em espécie. Em seguida o documento sugere uma expansão do conceito de renda, que incorpora algumas formas de natureza mais pontual (patrimônio) ou a renda implícita da produção para consumo próprio.

O enfoque é de natureza predominantemente econômica e, como veremos mais à frente, se ajusta ao marco metodológico estabelecido a partir da noção de renda de Hicks. Como o próprio documento reconhece, such an approach implies that it is current economic well-being which is of interest. Components which contribute to future economic well-being include employer contributions to pension funds and other forms of social insurance, interest earned on retirement-based assets and capital gains (Canberra Group, 2001, p. 12).

A leitura do documento indica que as propostas que ele carrega são orientadas para a construção de indicadores de bem-estar e de desigualdade. Apesar de complementares, estes dois temas não podem ser considerados como justapostos.

O primeiro tema tende, em geral, a xpressar tendência ou trajetória em termos de evolução média das condições econômica e social de vida de uma determinada 
população. Isto é, o aumento da renda média da população é normalmente tomado como uma proxy de uma melhora potencial do bem-estar da sociedade. Esta abordagem foi explorada em trabalhos clássicos, como os de Clark (1951) e Maddison (1995).

O outro tema volta-se para a análise da relação entre o aumento de bem-estar e o grau de heterogeneidade das condições econômicas e sociais que ele carrega. Isto é, é possível que o maior bem-estar esteja associado a uma desigualdade socioeconômica expressiva.

O documento da Organização Internacional do Trabalho (ILO, 2003) trilha percurso semelhante. As proposições foram organizadas pela Conferência Internacional de Estatísticos do Trabalho, que, em 2003, aponta novas orientações para os levantamentos estatísticos nacionais de renda dos domicílios.

A perspectiva por ele adotada é convergente com aquela encontrada no documento do Canberra Group (2001), como o próprio documento explicitamente reconhece (ILO, 2003, p. 8). Suas sugestões se voltam para a captação das rendas oriundas da produção para próprio consumo, de propriedade, de uso do domicílio de propriedade própria e das diversas formas de transferências públicas. Apesar da sua convergência com o documento do Canberra Group, o documento da OIT é mais explícito quanto ao escopo de suas proposições. De acordo com o texto, three principles usually discussed in connection with the definition of income for a specified reference period are: (1) receipts should be expected to recur regularly to be considered as "income"; (2) to be considered as "income", receipts should contribute to current economic well-being; (3) receipts arising from a reduction in net worth should be excluded from the concept of income (ILO, 2003, p. 8). Ademais, o conceito de renda is defined as the sum of consumption expenditure and change in net worth in a period (ILO, 2003, p. 9), seguindo a perspectiva estabelecida por Hicks (ILO, 2003, p. 9).

O documento da OIT se enquadra totalmente nos marcos metodológicos encontrados tanto em documentos produzidos anteriormente pela própria instituição para a mensuração da condição de trabalho e de renda (ILO, 1998), como pelos elaborados pela ONU e outras instituições multilaterais para a contabilidade das contas nacionais (SNA, 1993). Ele busca preservar, em grande medida, o conceito de renda de natureza monetária. Ainda, segundo o documento, in the system proposed ... an important consideration is that it should be possible to separately identify income arising out of employment-related activity within the larger component of income from productive activity. Income is thus defined in terms of a broad grouping of sources of income as follows: (1) income from employment comprises receipts from involvement in economic activities, strictly in an employment-related capacity as defined in the ICLS resolution concerning statistics of the economically active population, employment, unemployment and underemployment (ILO, 2000). It consists of employee income (e.g. wages) and self-employment income (return to labour); (2) property income from ownership of financial and other assets, e.g. interest payments; (3) income from household production of services for own consumption, e.g. services of owner-occupied housing, household 
production of domestic services for own consumption; (4) transfers received in cash and goods from government (e.g. pensions), other households (e.g. alimony, parental support) and non-profit institutions serving households (NPISH) (e.g. scholarships, strike pay); (5) transfers received as services, e.g. social transfers in kind (STIK), care services from other households. Income as defined is total or gross income before any deductions, compulsory or otherwise. For most micro-analysts, the most relevant concept is in fact disposable income ... (ILO, 2003, p. 12).

A proposição da OIT considera relevante o conceito de renda total ou bruta para a análise de natureza macro e o de renda disponível - excluídos os impostos, as taxas e as contribuições sociais - em um enfoque micro. Ela não faz qualquer menção à possibilidade de se analisar a capacidade de renda e consumo real e potencial dos domicílios para além dos marcos convencionalmente adotados, que são reconhecidamente aqueles propostos por Hicks. Percebe-se, deste modo, que tanto a OIT quanto o Canberra Group atualizam o conceito de renda que consideram relevante para mensurar o bem-estar das famílias, desde que o marco proposto por Hicks não seja colocado em questão. Neste sentido, ambos os documentos desconsideram tanto os problemas de mensuração da renda apontados na literatura resenhada anteriormente, como a necessidade de incorporar às rendas bruta/corrente ou disponível aspectos de natureza não monetária e mesmo minimamente tangíveis.

As tentativas de resposta a esta indagação não aparecem nos documentos destas instituições, mas nos esforços que pesquisadores ou instituições nacionais realizam ante a necessidade de ter um conhecimento adequado sobre o bem-estar e a desigualdade de seus povos.

Uma perspectiva que busca ampliar o enfoque sobre o bem-estar e a desigualdade tem sido desenvolvida pelo Levy Economics Institute of Bard College dos Estados Unidos. Ela mantém o foco na renda monetária, mas incorpora transferências não monetárias e também procura avaliar a importância da renda associada ao estoque de riqueza (net worth), com a preocupação de expressar melhor a complexidade das formas de rendimentos no capitalismo atual. Três são as inovações adotadas: (1) renda da posse de ativos financeiros e de propriedades que não sejam para uso próprio, (2) as transferências não monetárias governamentais e (3) o consumo de bens públicos.

De acordo com documento produzido recentemente pela instituição, there are three key motivations behind constructing Levy Institute Measure of Economic Well-Being - LIMEW. First, trends in well-being are sensitive to how we choose to measure well-being. A broader measure of well-being might be a better guide to actual trends in the standard of living. Second, another motivation behind developing the LIMEW is to study disparities among key demographic groups. By focusing only on money income, we might end up with a partial picture of the relative advantage of one particular group over another. Third, LIMEW provides a more comprehensive measure of economic inequality. As one might expect, household production and public consumption are distributed much more equally than earnings among households. On the other hand, inequality in wealth is generally 
much higher than that of income or earnings. LIMEW allows us to estimate the net effect of including both components (Wolff et al., 2009).

A metodologia proposta pelo LIMEW descarta um dos pressupostos adotados tanto pelo Canberra Group como pela OIT: a restrição de Hicks quanto à estabilidade da riqueza para a determinação da renda disponível. Como um dos autores do documento afirma em outro ensaio, Hicks adota uma racionalidade em que a renda e os preços esperados (ex-ante) são idênticos à renda e aos preços realizados (ex-post), de tal modo que seria possível conhecer tanto a evolução dos preços dos ativos quanto a renda auferida, compatível com a estabilidade do estoque (Zacharias, 2002).

Segundo Keynes, isto não seria possível. Mesmo adotando a hipótese bastante restritiva de condições técnicas dadas no período de produção, Keynes afirmava que os empresários podem decidir quanto produzir e ter uma expectativa de preço de venda. Mas não podem definir este preço nem a receita global. Ambos são somente conhecidos com a venda realizada e considerando os estoques existentes (Keynes, 1973, pp. 179-183). Portanto, a receita somente pode ser conhecida ex-post. Isto vale tanto para os empresários como para as famílias.

A perspectiva procura conhecer o poder efetivo de renda dos indivíduos e das famílias, entendendo que aquele oriundo da posse de ativos financeiros, por exemplo, se constitui em um diferencial importante para a diferenciação das condições de bem-estar da população. Ao invés de considerar o estoque de riqueza (net worth) como tendo um efeito residual sobre a desigualdade, entende que ele joga papel relevante neste processo.

Tal preocupação é fundamental se consideradas as transformações no capitalismo nestes últimos 30 anos, como a corrosão da sociedade salarial. O processo de formação das rendas, como já apontado anteriormente, se tornou mais complexo, tanto no que se refere àquela auferida através do trabalho, como no que diz respeito à resultante da posse da diversidade de ativos.

A dificuldade do conceito de renda monetária corrente é tal que estudos reconhecem ser respeitável a subdeclaração de rendimentos em pesquisas de origem domiciliar (Weinberg, 2004 e 2006, e Pikketi, 2001), sendo que o problema decorre, ao menos parcialmente, da complexidade da formas de rendimentos auferidos pelos indivíduos e famílias. Segundo estudo detalhado sobre o patrimônio das famílias, some of the most striking effects are the broadening of the stockholder base, the growth in mutual fund participation, the increasing importance of private pension funds, and the enthusiastic employee response to retirement accounts (such as 401( $k$ ) accounts in the United States). On the liability side, there has been fast growth in credit card use and in consumer indebtedness, debt often coexisting with asset holdings offering lower rates of return than loan rates (Guiso et al., 2002, p. 1).

A constatação da difusão da gestão de ativos no âmbito das famílias, como discute Guiso et al. (2001), se traduz ademais em uma distribuição muito desigual dos mesmos entre famílias segundo estratos de renda. As famílias de menor renda têm muitas vezes patrimônio líquido negativo. Quando positivo, ele tem a função de dar algumas proteção em relação a algum risco futuro concentrado na proprie- 
dade da residência para próprio uso. A situação das famílias de alta renda apresenta características contrárias. A gestão do patrimônio visa à acumulação de riqueza e extrapola a necessidade de proteção em relação a algum risco futuro, sendo fonte de geração adicional de capacidade de gasto.

Portanto, a posse de patrimônio joga um papel diferente segundo a renda das famílias, seja em termos de proteção, seja em termos de acumulação e geração de renda adicional. A distribuição desigual da riqueza em alguns países desenvolvidos expressa pela elevada participação dos estratos superiores, cabendo ao último decil ao redor de $50 \%$ do estoque, e um índice de concentração (Gini) igual ou superior a 0.60 , evidencia o potencial que a posse de ativos apresenta para a dinâmica da desigualdade.

A importância da riqueza para a dinâmica da desigualdade foi objeto de importante reflexão no início do século passado. Tawney (1995) e Webb e Webb (1995), professores da London School of Economics, elaboraram ensaios relevantes sobre a situação inglesa, mostrando que a posse de riqueza no capitalismo monopolista era fator determinante do estado de desigualdade da sociedade inglesa. Os trabalhos realizados na LSE acabaram por influenciar o Plano Beveridge, que deu origem naquele país ao estado de bem-estar.

A posse de ativos com capacidade de gerar acumulação de patrimônio e ampliação da renda e do gasto das famílias gera a possibilidade de investimento em educação e em acesso às diversas formas de conhecimento e cultura, como de línguas estrangeiras, pelas famílias de alta renda são fontes potenciais de reprodução futura da desigualdade, mas podem não influenciar sua situação no presente. Neste sentido, indicadores de acesso a bens públicos tendem a ser relevantes para compreender a desigualdade.

Esta orientação tem sido proposta por Osberg e Sharpe (2002), que consideram necessário tratar da desiguadade de maneira multidimensional. Os autores sugerem quatro componentes: (a) effective per capita consumption flows, including consumption of marketed goods and services; government services; effective per capita flows of household production; leisure; and changes in life span; (b) net societal accumulation of stocks of productive resources, including net accumulation of tangible capital; housing stocks; net changes in the value of natural resources stocks; environmental costs; net changes in the level of foreign indebtedness; accumulation of human capital; and the stock of R\&D investment; (c) Income distribution, including the intensity of poverty (incidence and depth) and the inequality of income; $e$ (d) Economic security from job loss and unemployment, illness, family breakup, and poverty in old age (Osberg e Sharpem, 2002).

A proposta dos autores retoma a perspectiva que haviam trabalhado Nordhauss e Tobin (1973) e as sugestões feitas por Kuznets (1973), que foram já exploradas anteriormente. Ela rompe com a tradição de focar a discussão, tanto de bem-estar como de desigualdade, na renda, bem como procura construir indicadores de natureza dinâmica. Isto é, com potencial de afetar a tendência futura da desigualdade. Os autores explicitam a necessidade de se discutir os elementos cumu- 
lativos da desigualdade, isto é, que relacionem a situação presente à futura, recolocando também a importância de uma abordagem multidimensional.

Esta linha de abordagem não refuta a renda como uma dimensão importante para a caracterização da situação atual de desigualdade. A contribuição que ela aporta volta-se para entender as diversas formas de renda monetária como uma ou umas das dimensões do problema, havendo necessidade de construir outras dimensões de natureza monetária ou não, como o acesso aos bens públicos e à tecnologia da informação ou à exposição ao desemprego.

\section{OBSERVAÇÕES FINAIS}

O ponto de partida deste ensaio foi o reconhecimento do problema da desigualdade pelas instituições multilateriais, cujos estudos argumentam pela necessidade de uma abordagem mais ampla sobre o problema. Com base nesta preocupação, foi recuperado um conjunto de esforços, realizados ao menos desde os anos 1930, que problematizaram as dificuldades de tratar do tema a partir da renda monetária corrente e que sugeriram um escopo analítico mais amplo.

O fim da era de crescimento do capitalismo no final dos anos 1970 trouxe consigo um conjunto de transformações econômicas, sociais, políticas e tecnológicas que vieram reordenando o tecido econômico e as relações sociais existentes, com recorrente reestruturação das instituições de toda natureza e das políticas públicas. O recuo da renda do trabalho no PIB, a fragmentação da relação e do contrato de trabalho, a ampliação das políticas públicas, o processo complexo de financeirização da riqueza, as novas tecnologias, dentre outros, modificaram fortemente os determinantes da desigualdade, tornando menos abrangente a capacidade explicativa da renda monetária corrente para a evolução da desigualdade. Tanto outras formas de renda como outros bens e serviços não monetários devem ser considerados para entendimento do problema no capitalismo atual.

A resposta a esta pergunta passa pela construção de uma visão multidimensional que considere a renda monetária corrente, mas que leve em conta tantos as outras formas monetárias de renda como o acesso a bens e serviços não monetários. E que assuma algum tipo de enfoque dinâmico da desigualdade.

Uma parte deste trajeto de construção de uma nova metodologia e do enfoque sobre desigualdade pode contar com a ampla e rica literatura existente. Porém, um esforço razoável necessita ser realizado na elaboração de uma abordagem multidimensional.

Apesar do considerável desafio que tal tarefa coloca, pode-se dizer que uma questão está clara. A desigualdade que procuramos conhecer é muito mais ampla e complexa que aquela que o enfoque na renda pode nos oferecer. 


\section{REFERÊNCIAS BIBLIOGRÁFICAS}

CANBERRA GROUP (2001) Expert Group on Household Income Statistic, Final Report and Recommendations. Otawa: The Canberra Group.

CLARK, C. (1951) The Conditions of Economic Progress. London: Macmillan.

EISNER, R. (1989) "Divergences of measurement and theory and some implications for economic policy", The American Economic Review 79, 1. New York: American Economic Association.

GALBRAITH, J.K. (2005) "Global inequality and global policy”. Journal of Catholic Social Thought, Vol 2., No. 1.

GUISO, L.; HALIASSOS, M.; JAPELLI, T. (2002) “Introduction” in L. Guiso, M. Haliassos e T. Japelli, Household Portfolios. Cambrige: The MIT Press.

HAIG, R.M. (1921) “The concept of income-economic and legal aspects" in Robert M. Haig, The Federal Income Tax New York: Columbia University Press.

HICKS, J.R. (1939) Value and Capital. Oxford: Clarendon Press.

HICKS, J.R. (1940) “The valuation of the social income”, Economica, New Series, Vol. 7, No. 26, May. London: Blackwell Publishing/London School of Economics and Political Science.

HICKS, J.R. (1948) "The valuation of the social income-a comment on Professor Kuznets' reflections", Economica, New Series, Vol. 15, No. 59, Aug. London: Blackwell Publishing/London School of Economics and Political Science.

ILO - International Labour Organization, (2003) Household income and expenditure Statistics, Seventeenth International Conference of Labour Statisticians. Geneva: International Labour Organization.

ILO - International Labour Organization (1998) Measurement of income from employment, Report II, Sixteenth International Conference of Labour Statisticians. Geneva: International Labour Organization.

JUSTER, T. (1973) "A framework for the measurement of economic and social performance" in M. Moss, The Measurement of Economic and Social Performance. New York: National Bureau of Economics Research/Columbia University Press.

KEYNES, J.M. (1973) "Ex-post and ex-ante" in D.D. Moggridge, The Collected Writings of John Maynard Keynes, vol XIV (The General Theory and After). Londres: Macmillan.

KUZNETS, S. (1948a) "On the valuation of social income-reflections on Professor Hicks - Part I", Economica, New Series, Vol. 15, No. 57, Feb. London: Blackwell Publishing/London School of Economics and Political Science.

KUZNETS, S. (1948b) "On the valuation of social income-reflections on Professor Hicks - Part II", Economica, New Series, Vol. 15, No. 58, May. London: Blackwell Publishing/London School of Economics and Political Science.

KUZNETS, S. (1955) "The economics growth and income inequality", The American Economic Review, 45(1), Mar. New York: American Economic Association.

KUZNETS, S. (1973) "Remarks" in M. Moss, The Measurement of Economic and Social Performance. New York: National Bureau of Economics Research/Columbia University Press.

MADDISON, A. (1995) Monitoring the World Economy 1820-1992. Paris: OECD.

MARSHALL, T.H. (1967) Social Policy in the Twentieth Century. London: Hutchinson.

MOSS, M. (1973) The Measurement of Economic and Social Performance. New York: National Bureau of Economics Research/Columbia University Press.

NORDHAUS, W.D. \& TOBIN, J. (1973) "Is growth obsolets?" in M. Moss, The Measurement of Economic and Social Performance. New York: National Bureau of Economics Research/Columbia University Press.

MUSGRAVE, R.A. (1985) "A brief history of fiscal doctrine" in Alan J. Auerbach and Martin Feldstein, Handbook of Public Economics. New York: North-Holland.

OSBERG, L. \& SHARPE, A. (2002) “An index of economic well-being for select OECD countries", Review of Income and Wealth, 48(3). Ontario: International Association for Research in Income and Wealth/Blackwell Publishing.

PIKKETI, T. (2001) Les hauts revenus en France au XXe Siècle. Paris: Grasset. 
POLANYI, K. (2001) The Great Transformation, The Political and Economics Origins of our Time. Boston: Beacon Press.

SACHS, J. (2005) The End of Poverty: Economic Possibilities for Our Time. London: Penguin Press.

SNA - System National Accounts (1993) System of national accounts, Brussels, Luxembourg, New York, Paris, Washington, DC.; EUROSTAT, IMF, OECD, United Nations and World Bank.

SHONFIELD, A. (1965) Modern Capitalism. Oxford: Oxford University Press.

SIMONS, H.C. (1938) Personal Income Taxation: The Definition of Income as a Problem of Fiscal Policy. Chicago: Chicago University Press.

TAWNEY, R.H. (1995) “The religion of inequality” in M. Desai, LSE on Equality. London: London School of Economics.

WEBB, S. \& WEBB, B. (1995) "Inequality of income and inequality of personal freedom" in M. Desai, LSE on Equality. London: London School of Economics.

WEBER, M. (1992) The Protestant Ethic and the Spirit of Capitalism, London: Routledge.

WEINBERG, D.H. (2004) Income Data Quality Issues in the Annual Social and Economic Supplement to the Current Population Survey. Washington, DC: US Census Bureau.

WEINBERG, D.H. (2006) "Income data quality issues in the CPS", Monthly Labor Review, June. Washington, DC: Bureau of Labor Statistics.

WOLFF, E.; ZACHARIAS, A.; MASTERSON, T. (2009) "Long-term tends in the levy institute of measurement of economic well-being (LIMEW), United States, 1959-2004”, Working Paper 556. Annandale-on-Hudson: The Levy Economics Institute.

ZACHARIAS, A. (2002) “A note on the Hicksian concept of income”, Levy Institute of Bard College Working Paper, 342. Annandale-on-Hudson: Levy Economics Institute. 